\title{
Synthesis, characterization and thermal behavior of solid state 2-methoxybenzylidenepyruvate of alkali earth metals, except beryllium and radium
}

\author{
L. H. Bembo Filho ${ }^{1}$, E. Y. Ionashiro ${ }^{1 *}$, C. T. Carvalho ${ }^{3}$; A. B. Siqueira ${ }^{2}$ \\ ${ }^{1}$ Instituto de Química, UFG, Campus II, 74001-979, Goiania-GO, Brazil. \\ ${ }^{2}$ Instituto de Ciências Exatas e da Terra, UFMT, Campus Pontal do Araguaia, 78698-000, Pontal do Araguaia-MT, Brazil. \\ ${ }^{3}$ Universidade Federal da Grande Dourados, CEP 79.804-970, Dourados, MS, Brazil.
}

Received 27/03/2013; Accepted 11/12/2013

Available online 18/12/2013

\begin{abstract}
Solid state $\mathrm{M}(2-\mathrm{MeO}-\mathrm{BP})_{2}$ compounds, where $\mathrm{M}$ stands for bivalent alkali earth metal ions $(\mathrm{Mg}, \mathrm{Ca}, \mathrm{Sr}$ and $\mathrm{Ba})$ and 2-MeO-BP is 2-methoxybenzylidenepyruvate, have been synthesized. Simultaneous thermogravimetry and differential thermal analysis (TG-DTA), differential scanning calorimetry (DSC), infrared spectroscopy, elemental analysis and complexometry, were used to investigate these compounds. The dehydration of magnesium, strontium and barium compounds occurs in a single step, while for calcium compound the dehydration occurs in two steps. The thermal decomposition of the anhydrous compounds occurs with the formation of carbonate as intermediate, except for the magnesium compound. The results also provided information about the composition, coordination mode, thermal behavior and thermal decomposition of isolated compounds.
\end{abstract}

Keywords: alkali earth metals, 2-methoxybenzylidenepyruvate, thermal behavior.

\section{Introduction}

Several works in the literature reports synthesis of benzylidenepyruvic acid (HBP) and its phenyl-substituted derivatives [1, 2$]$. These acids are of continuing interest as intermediates in pharmacological, industries and chemical syntheses, in development of enzyme inhibitors and drugs, as model substrates of enzymes [2-4]. Synthesis and investigation of several metal- ion complexes of phenylsubstituted derivatives of $\mathrm{BP}$, have been carried out in aqueous solutions [ [ $]$ ] and in solid state [2, 7-11]. In aqueous solutions, these works reported mainly the thermodynamic stability $\left(\beta_{1}\right)$ and spectroscopic parameters $\left(\varepsilon_{1 \max }, \lambda_{\max }\right)$, associated with 1:1 complex species, analytical applications of the ligands, e.g., in gravimetric analysis and as metalochromic indicators. In solid state, the establishment of the stoichiometry and detailed knowledge of the thermal behaviour of ligands and their metal ion compounds have been the main purposes of the studies.

In the present paper, solid state compounds of some alkali earth metal ions $\left(\mathrm{Mg}^{2+}, \mathrm{Ca}^{2+}, \mathrm{Sr}^{2+}\right.$ and $\left.\mathrm{Ba}^{2+}\right)$ with 2-Methoxybenzylidenepyruvate $\left(2-\mathrm{CH}_{3}-\mathrm{O}-\mathrm{C}_{6} \mathrm{H}_{4}-\mathrm{CH}=\right.$ $\mathrm{CH}-\mathrm{COCOO}^{-}$) were prepared. The compounds were investigated by complexometry, elemental analysis, infrared spectroscopy, simultaneous thermogravimetry and differential thermal analysis (TG-DTA) and differential scanning calorimetry (DSC). The results allowed us to acquire information concerning these compounds in the solid state, including their thermal stability and thermal decomposition.

\section{Experimental}

The sodium salt of 2-methoxybenzylidenepyruvate acid (Na-2-MeO-BP) was prepared following the same procedure as described in the references [12-14]. Aqueous solution of $\mathrm{Na}-2-\mathrm{MeO}-\mathrm{BP} 0,1 \mathrm{Mol} \mathrm{L}{ }^{-1}$ was prepared by direct weighting of the salt.

Magnesium, calcium, strontium and barium solutions were prepared from the corresponding metal carbonates by treatment with diluted hydrochloric acid. The solutions were transferred to a volumetric flask and diluted in order to obtain ca. $0,1 \mathrm{~mol} \mathrm{~L}^{-1}$ solutions, whose $\mathrm{pH}$ were adjusted to 5 by adding diluted sodium hydroxide or hydrochloric acid solutions.

The solid state compounds were prepared by adding slowly with continuous stirring, the solution of the ligand to the respective metal solutions, until total precipitation of metal ions. The precipitates were washed with distillated water until elimination of chloride ion, filtered through and dried on Whatman $n^{\circ} 42$ filter paper, and kept in a desiccator over anhydrous calcium chloride, under reduced pressure.

In the solid state compounds, hydration water, ligand and metal ion contents were determinated from the TG curves. The metal ions were also determinated by complexometric titrations with standard EDTA solutions, using eriochrome black $\mathrm{T}$ as indicator for magnesium, eriochrome blue black $\mathrm{R}$ for calcium and methylthymol blue for strontium and barium. Carbon and hydrogen microanalysis were performed by using EA 1110, CHNS-O Elemental analyzer (CE Instruments). 
The diffuse reflectance infrared spectra for $\mathrm{Na}-2-\mathrm{MeO}-\mathrm{BP}$, as well as for its metal-ion compounds were run on a Nicolet iS10 FT-IR spectrophotometer, using an ATR accessory with Ge window.

Simultaneous TG-DTA and DSC curves were recorded in a models SDT 2960 and Q10, both from TA instruments. The purge gas was an air flow of $100 \mathrm{~mL} \mathrm{~min}{ }^{-1}$. A heating rate of $20{ }^{\circ} \mathrm{C} \mathrm{min}{ }^{-1}$ was adopted, with samples weighting about $7 \mathrm{mg}$. Alumina and aluminum crucibles, the latter with perforated covers, were used for TG-DTA and DSC, respectively.

\section{Results and Discussion.}

The analytical and thermoanalytical results are shown in Table 1. The results permitted to establish the stoichiometry of the compounds, which is in agreement with the general formula $\mathrm{M}(2-\mathrm{MeO}-\mathrm{BP})_{2} . \mathrm{nH}_{2} \mathrm{O}$, where $\mathrm{M}$ represents alkali earth metal ions, 2-MeO-BP is 2-methoxybenzylidenepyruvate and $\mathrm{n}=3.5(\mathrm{Mg}) ; 4(\mathrm{Ca})$; and $1(\mathrm{Sr}$ and $\mathrm{Ba})$.

Table 1. Analytical data for the $\mathrm{Ln}(\mathrm{L}) 3 \mathrm{n} \mathrm{H} 2 \mathrm{O}$ compounds. as coordination center in the metal compounds. The difference between the values of anti-symmetrical and symmetrical carboxylate vibration of the synthesized compounds in comparison with the ones found on 2-MeO-BP itself (sodium salt), can suggest which interaction, between metal and ligands are being made. $[\underline{15}, \underline{16}]$

The bands corresponding to ketonic carbonyl, antisymmetrical and simetrical carboxylate vibration, found for the studied compounds are in the same region to the ones found for Na-2-MeO-BP. This behavior is in disagreement with $2-\mathrm{MeO}-\mathrm{BP}$ compounds with other metals $[\underline{13}, \underline{14}, \underline{17}$, 18], suggesting an ionic interaction between the ligand and the studied metals $[\underline{15}, \underline{16}]$.

Simultaneous TG-DTA curves of the compounds are shown in Fig.1. These curves exhibit mass losses in three or four consecutive and/or overlapping steps and thermal events which are characteristic for each compound.

For magnesium compound, the first mass loss (range: $75-171^{\circ} \mathrm{C}$ ) associated to the endothermic peak at $123^{\circ} \mathrm{C}$ in DTA curve and $129^{\circ} \mathrm{C}$ in DSC one, is ascribed to the dehydration with loss of $3.5 \mathrm{H}_{2} \mathrm{O}$, which occurs in a single step. Once dehydrated the compound is stable up to $229^{\circ} \mathrm{C}$.

\begin{tabular}{|c|c|c|c|c|c|c|c|c|c|c|c|c|}
\hline $\mathrm{Mg}(\mathrm{L})_{2} \cdot 3.5 \mathrm{H}_{2} \mathrm{O}$ & 4.88 & 4.78 & 4.9 & 79.22 & 79.11 & 12.67 & 12.57 & 25.16 & 26.10 & 1.79 & 1.82 & $\mathrm{MgO}$ \\
\hline $\mathrm{Ca}(\mathrm{L})_{2} \cdot 4 \mathrm{H}_{2} \mathrm{O}$ & 7.67 & 7.15 & 7.7 & 75.46 & 76.40 & 13.80 & 13.21 & 25.27 & 24.33 & 1.74 & 1.60 & $\mathrm{CaO}$ \\
\hline $\mathrm{Sr}(\mathrm{L})_{2} .1 \mathrm{H}_{2} \mathrm{O}$ & 16.99 & 16.85 & 17.12 & 76.42 & 75.82 & 3.49 & 4.20 & 25.59 & 26.10 & 1.76 & 1.80 & $\mathrm{SrO}$ \\
\hline
\end{tabular}

Infrared spectroscopic data on 2-methoxybenzylidenepyruvate and its compounds are shown in Table 2. The investigation was focused mainly within the $1700-1400 \mathrm{~cm}^{-1}$ range because this region is potentially the most informative in attempting to assign coordination sites.

Table 2. Spectroscopic data for sodium 2-methoxybenzylidenepyruvate and for its compounds with alkali earth metal.

\begin{tabular}{lccccc}
\hline \multicolumn{1}{c}{ Compounds } & $\mathbf{v}_{(\mathbf{O}-\mathbf{H})}$ & $\mathbf{v}_{\mathbf{s}(\mathbf{C O O}-)}$ & $\mathbf{v}_{\text {as }(\mathbf{C O O}-)}$ & $\mathbf{v}_{(\mathbf{C}=\mathbf{O})}$ & $\boldsymbol{\Delta v}_{\text {(ass-sim) }}$ \\
\hline $\mathrm{NaL} .1 .5 \mathrm{H}_{2} \mathrm{O}$ & $3.470 \mathrm{~m}$ & $1.489 \mathrm{~m}$ & $1.571 \mathrm{~s}$ & $1.623 \mathrm{~s}$ & 82 \\
$\mathrm{Mg}(\mathrm{L})_{2} .3 .5 \mathrm{H}_{2} \mathrm{O}$ & $3.385 \mathrm{~m}$ & $1.486 \mathrm{~m}$ & $1.577 \mathrm{~s}$ & $1.591 \mathrm{~s}$ & 91 \\
$\mathrm{Ca}(\mathrm{L})_{2} .4 \mathrm{H}_{2} \mathrm{O}$ & $3.204 \mathrm{~m}$ & $1.490 \mathrm{~m}$ & $1.566 \mathrm{~s}$ & $1.622 \mathrm{~s}$ & 76 \\
$\mathrm{Sr}(\mathrm{L})_{2} .1 \mathrm{H}_{2} \mathrm{O}$ & $3.078 \mathrm{~m}$ & $1.487 \mathrm{~m}$ & $1.583 \mathrm{~s}$ & $1.621 \mathrm{~s}$ & 96 \\
$\mathrm{Ba}(\mathrm{L})_{2} .1 \mathrm{H}_{2} \mathrm{O}$ & $3.075 \mathrm{~m}$ & $1.486 \mathrm{~m}$ & $1.582 \mathrm{~s}$ & $1.629 \mathrm{~s}$ & 96
\end{tabular}

$\mathrm{L}=2$-methoxybenzylidenepyruvate; strong: $\mathrm{s}$; medium: $\mathrm{m} ; \mathrm{v}_{\mathrm{as}(\mathrm{O}-\mathrm{H})}=$ hydroxyl group stretching frequency; $v_{\mathrm{s}(\mathrm{COO}-)}$ and $v_{\mathrm{as}\left(\mathrm{COO}_{-}\right)}=$symmetrical and anti-symetrical vibrations of the $\mathrm{COO}$ - structure; $\mathrm{v}_{\mathrm{s}(\mathrm{C}=\mathrm{O})}=$ ketonic carbonyl stretching frequency.

According to Deacon and Phillips [15, 16], the variation in the values of the bands in these regions, in comparison to the corresponding frequencies in 2-MeO-BP itself (sodium salt), indicates that this group act

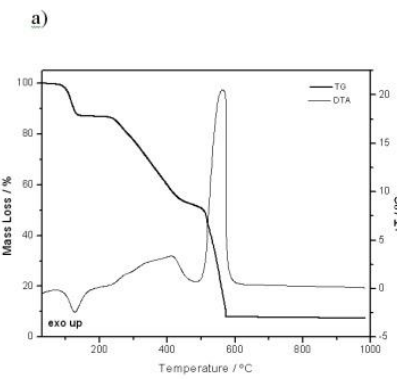

b) c)
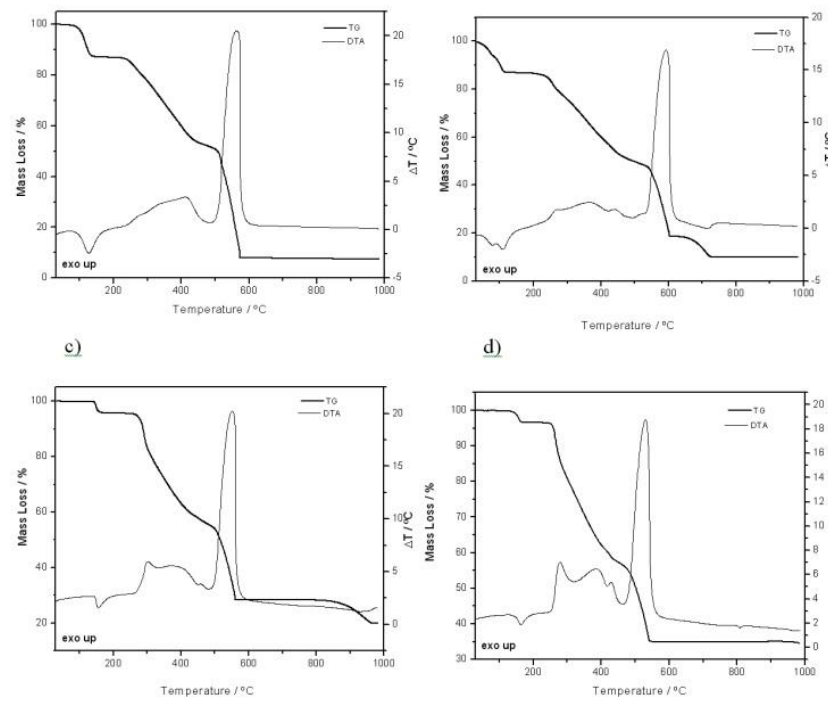

d)

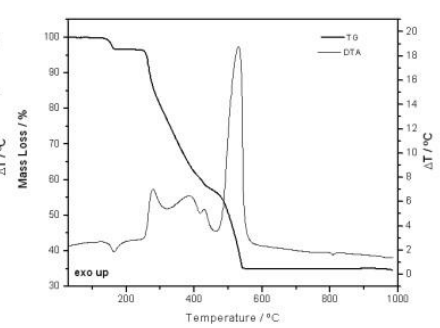

Figure 1. Simultaneous TG-DTA curves of the compound: a) $\mathrm{Mg}(2-\mathrm{MeO}-\mathrm{BP})_{2} \cdot 3.5 \mathrm{H}_{2} \mathrm{O}$; b) $\mathrm{Ca}(2-\mathrm{MeO}-\mathrm{BP})_{2} \cdot 4 \mathrm{H}_{2} \mathrm{O}$; c) $\mathrm{Sr}(2-\mathrm{MeO}-\mathrm{BP})_{2} \cdot 1 \mathrm{H}_{2} \mathrm{O}$; d) $\mathrm{Ba}(2-\mathrm{MeO}-\mathrm{BP})_{2} \cdot 1 \mathrm{H}_{2} \mathrm{O}$; heating rate: $20^{\circ} \mathrm{C} \mathrm{min}^{-1}$; air flow: $100 \mathrm{~mL} \mathrm{~min}^{-1}$

The second step (range: $229-513^{\circ} \mathrm{C}$ ) associated to the exothermic peaks at $270 ; 325$ and $410^{\circ} \mathrm{C}$ in DTA curve and $270^{\circ} \mathrm{C} ; 381^{\circ} \mathrm{C}$ and $415^{\circ} \mathrm{C}$, in DSC one, is attributed to the 
thermal decomposition of the compound. The profiles of DTA curve suggest that the thermal decomposition in this temperature range occurs in three or more consecutive steps. The last step (range: $513-583^{\circ} \mathrm{C}$ ) associated with the large exothermic peak at $574^{\circ} \mathrm{C}$ is attributed to the oxidation of organic matter with the formation of magnesium oxide, as final residue.

For the calcium compound, the first mass loss (range: $30-121^{\circ} \mathrm{C}$ ) associated to the exothermic peaks at $75^{\circ} \mathrm{C}$ and $110{ }^{\circ} \mathrm{C}$ (DTA) and $109^{\circ} \mathrm{C}$ (DSC), is ascribed to the dehydration with loss of $4 \mathrm{H}_{2} \mathrm{O}$, which occurs in two steps. The second step (range: $191-538^{\circ} \mathrm{C}$ ) associated to the exothermic peaks at $265 ; 365$ and $438^{\circ} \mathrm{C}$ (DTA) and $267^{\circ} \mathrm{C}$; $367^{\circ} \mathrm{C}$ and $454{ }^{\circ} \mathrm{C}$, (DSC), is attributed to the thermal decomposition of the compound. The DTA curve also suggests that the thermal decomposition of the compounds occurs in three or more consecutive steps. The third step (range: $538-604^{\circ} \mathrm{C}$ ) associated with the large exothermic peak at $593^{\circ} \mathrm{C}$ is attributed to the oxidation of organic matter with the formation of calcium carbonate as intermediate. Tests with hydrochloric acid solution on this intermediate, as indicated by corresponding TG-DTA curves confirmed the evolution of $\mathrm{CO}_{2}$ and presence of the carbonaceous residue. The last step (range: $604-722^{\circ} \mathrm{C}$ ) is due to the thermal decomposition of calcium carbonate and carbonaceous residue with the formation of calcium oxide, as final residue.

For the strontium compound, the first mass loss (range: $145-190^{\circ} \mathrm{C}$ ) associated to the exothermic peak at $156^{\circ} \mathrm{C}$ (DTA) and $160^{\circ} \mathrm{C}$ (DSC), is ascribed to the dehydration with loss of $1 \mathrm{H}_{2} \mathrm{O}$, which occurs in a single step. The second step (range: $266^{\circ}-486 \mathrm{C}$ ) associated to the exothermic peaks at $300 ; 383$ and $462^{\circ} \mathrm{C}$ (DTA) and $300^{\circ} \mathrm{C}$; $396^{\circ} \mathrm{C}$ and $470{ }^{\circ} \mathrm{C}$, (DSC), are attributed to the thermal decomposition of the compound. The DTA and DSC curves suggest that this decomposition occurs in three or more consecutive steps. The third step (range: $486-588^{\circ} \mathrm{C}$ ) associated with the large exothermic peak at $551^{\circ} \mathrm{C}$ (DTA) is attributed to the oxidation of organic matter with the formation of strontium carbonate as intermediate. Tests with hydrochloric acid solution on this intermediate, as indicated by corresponding TG-DTA curves confirmed the evolution of $\mathrm{CO}_{2}$ and presence of the carbonaceous residues. The last step (range: $815-968^{\circ} \mathrm{C}$ ) is due the thermal decomposition of strontium carbonate and carbonaceous residue with the formation of strontium oxide, as final residue.

For the barium compound, the first mass loss (range: $133-204^{\circ} \mathrm{C}$ ) associated to the exothermic peak at $163^{\circ} \mathrm{C}$ (DTA) and $157^{\circ} \mathrm{C}$ (DSC), is ascribed to the dehydration with loss of $1 \mathrm{H}_{2} \mathrm{O}$, which occurs in a single step. The second step (range: $254-438^{\circ} \mathrm{C}$ ) associated to the exothermic peaks at 287; 387 and $428^{\circ} \mathrm{C}$ (DTA) and $284^{\circ} \mathrm{C} ; 383^{\circ} \mathrm{C}$ and $437{ }^{\circ} \mathrm{C}$, (DSC), is attributed to the thermal decomposition of the compound. The DTA curves suggest that the thermal decomposition of the compound occurs in three or more consecutive steps. The third step (range: $438-543^{\circ} \mathrm{C}$ ) associated with the large exothermic peak at $530^{\circ} \mathrm{C}$ is attributed to the oxidation of organic matter with the formation of barium carbonate as final residue. Tests with hydrochloric acid solution on this residue confirmed the evolution of $\mathrm{CO}_{2}$.
After the dehydration the formation of stable anhydrous compound is observed for all the compounds.

The mass losses, temperature ranges and the peak temperatures observed for each step of the TG - DTA curves are shown in Table 3.

Table 3. Temperature ranges $\theta$, mass losses (\%) and peak temperatures observed for each step of the TG-DTA curves of the compounds. $\mathrm{M}(\mathrm{L}) 3 . \mathrm{nH} 2 \mathrm{O}$, where $\mathrm{M}=$ alkali earth metal, L= 2-methoxybenzylidenepyruvate.

\begin{tabular}{|c|c|c|c|c|c|}
\hline \multirow{2}{*}{ Compound } & & \multicolumn{4}{|c|}{ Steps } \\
\hline & & First & Second & Third & Fourth \\
\hline \multirow{4}{*}{$\mathrm{Mg} \mathrm{L}_{2} .3 .5 \mathrm{H}_{2} \mathrm{O}$} & $\theta^{\circ} \mathrm{C}$ & $75-171$ & $229-513$ & $513-583$ & - \\
\hline & Loss (\%) & 12.57 & 35.73 & 21.18 & - \\
\hline & & & 270 (exo) & & - \\
\hline & Peak $\left({ }^{\circ} \mathrm{C}\right)$ & 123 (endo) & $\begin{array}{l}325 \text { (exo) } \\
410 \text { (exo) }\end{array}$ & 574 (exo) & \\
\hline \multirow[b]{3}{*}{$\mathrm{Ca} \mathrm{L}_{2} \cdot 4 \mathrm{H}_{2} \mathrm{O}$} & $\theta^{\circ} \mathrm{C}$ & $30-121$ & $191-538$ & $538-604$ & $604-722$ \\
\hline & Loss $(\%)$ & 13.21 & 38.93 & 29,35 & 8.587 \\
\hline & Peak $\left({ }^{\circ} \mathrm{C}\right)$ & $\begin{array}{c}75 \text { (endo) } \\
110 \text { (endo) }\end{array}$ & $\begin{array}{l}265 \text { (exo) } \\
365 \text { (exo) } \\
593 \text { (exo) }\end{array}$ & 593 (exo) & - \\
\hline \multirow{3}{*}{$\mathrm{Sr} \mathrm{L}_{2} .1 \mathrm{H}_{2} \mathrm{O}$} & $\theta^{\circ} \mathrm{C}$ & $145-190$ & $266-486$ & $486-588$ & $815-968$ \\
\hline & Loss (\%) & 4.20 & 40.42 & 27.06 & 8.44 \\
\hline & Peak $\left({ }^{\circ} \mathrm{C}\right)$ & 156 (endo) & $\begin{array}{l}300 \text { (exo) } \\
383 \text { (exo) } \\
466 \text { (exo) }\end{array}$ & 551 (exo) & \\
\hline \multirow{3}{*}{$\mathrm{Ba} \mathrm{L} .1 \mathrm{H}_{2} \mathrm{O}$} & $\theta^{\circ} \mathrm{C}$ & $133-204$ & $240-438$ & $438-543$ & - \\
\hline & Loss $(\%)$ & 3.40 & 38.88 & 22.67 & - \\
\hline & Peak $\left({ }^{\circ} \mathrm{C}\right)$ & 163 (endo) & $\begin{array}{l}287 \text { (exo) } \\
387 \text { (exo) } \\
428 \text { (exo) }\end{array}$ & 530 (exo) & - \\
\hline
\end{tabular}

The DSC curves of the compounds are shown in Fig. 2 and the dehydration enthalpies found for these compounds $(\mathrm{Mg}, \mathrm{Ca}, \mathrm{Sr}$ and $\mathrm{Ba})$ were: 179.83, 87.7, 48.29 and $66.7 \mathrm{~kJ} \mathrm{~mol}^{-1}$, respectively.

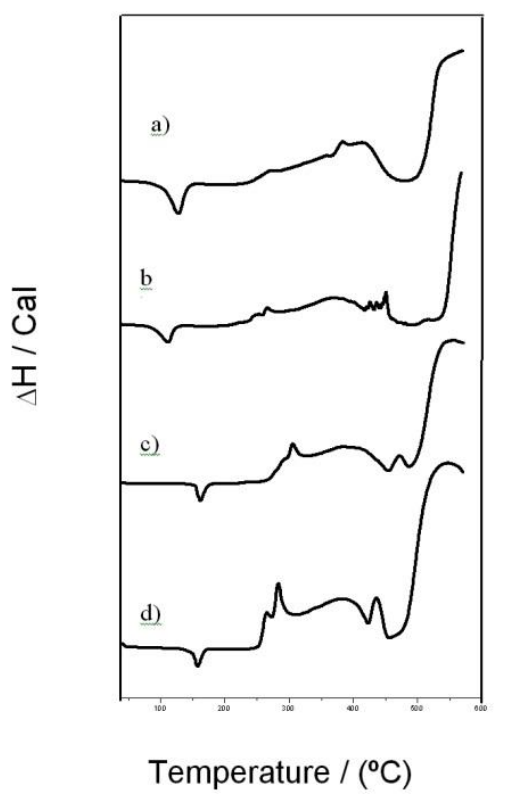

Figure 2. $\mathrm{DSC}$ curves of the: a) $\mathrm{Mg}(2-\mathrm{MeO}-\mathrm{BP})_{2} \cdot 3,5 \mathrm{H}_{2} \mathrm{O}$; b) $\mathrm{Ca}(2-\mathrm{MeO}-\mathrm{BP})_{2} \cdot 4 \mathrm{H}_{2} \mathrm{O} ; \quad$ c) $\mathrm{Sr}(2-\mathrm{MeO}-\mathrm{BP})_{2} \cdot 1 \mathrm{H}_{2} \mathrm{O}$; d) $\mathrm{Ba}(2-\mathrm{MeO}-\mathrm{BP})_{2} \cdot 1 \mathrm{H}_{2} \mathrm{O}$. 


\section{Conclusions}

From TG curves, elemental analysis and complexometry results, a general formula could be established for these compounds in solid state.

The infrared spectroscopic data suggest that 2-MeO-BP acts as an ionic ligand towards the metal ions considered in this work.

The TG-DTA curves show that the dehydration occurs in a single step, except for the calcium compound and the thermal decomposition of the anhydrous compound occurs with the formation of the metal carbonate except for the magnesium compound.

The TG-DTA and DSC curves also provided previously unreported information concerning the thermal behavior and thermal decomposition of these compounds which have been synthesized and reported for the first time.

\section{Acknowledgements}

The authors thank FAPESP (Proc. 97/12646-8), CAPES, CNPq Foundations Edital universal (Brazil) for financial support and Prof. Massao Ionashiro for permitting the use of all the equipments (TG-DTA, DSC, FTIR) and of his laboratory (IQ- Araraquara- Unesp).

\section{References}

[1] Ferrara S, Mapellia E, Sellob G, Gennaroa P. Characterization of the aldol condensation activity of the trans-o-hydroxybenzylidenepyruvate hydratasealdolase (tHBP-HA) cloned from Pseudomonas fluorescens N3. Biochim. Biophys. Acta, Prot. Proteo. 2011:1814(5):622-9. [Google Scholar] [PubMed] [CrossRef]

[2] Kobelnik M, Schnitzler E, Ionashiro M. Solid-state compounds of 2-methoxybenzylidenepyruvate with some bivalent metal ions - Synthesis, characterization and thermal behavior studies. J. Therm. Anal. Cal. 2008:91(3):891-5. [Google Scholar] [Visualizar Item] [CrossRef]

[3] Shiri M, Heravi M. Soleymanifard B. Arylidene pyruvic acids (APAs) in the synthesis of organic compounds. Tetrahedron 2012:68:6593-650. [Google Scholar [CrossRef]

[4] Brown E, Dujardin G, Maudet M. Total synthesis of (-)-O-dimethylsugiresinol, involving asymmetric [4+2] heterocycloaddition of a styrene with a benzylidenepyruvic ester of an $\alpha$-O-silyl derivative of (D)-erythronolactone. Tetraedron 1997:53(28):9679-94. [Google Scholar] [CrossRef]

[5] Dujardin G, Leconte S, Bénard A, Brown E. A Straightforward Route to E- $\gamma$-Aryl- $\alpha$-oxobutenoic Esters by One-step Acid-catalysed Crotonisation of Pyruvates. Synllet 2001:1:147-9. [Google Scholar] [CrossRef]
[6] Marques RN, Melios CB, Pereira NCS, Siqueira OS, Moraes M, Molina M, Ionashiro M. Complexation of some trivalent lanthanides, scandium (III) and thorium (IV) by benzylidenepyruvates in aqueous solution. J. Alloys Comps. 1997: 249: 102-5. [Google Scholar] [CrossRef

[7] Oliveira LCS, Melios CB, Crespi Spirandeli M, Ribeiro CA, Ionashiro M. Preparation and thermal decomposition of solid state compounds of 4-methoxybenzylidenepyruvate and trivalent lanthanides and yttrium. Thermochim. Acta 1993:219:215-24. [Google Scholar] [CrossRef]

[8] Miyano MH, Melios CB, Ribeiro CA, Redigolo H, Ionashiro $\mathrm{M}$. The preparation and thermal decomposition of solid state compounds of 4-dimethylaminobenzylidenepyruvate and trivalent lanthanides and yttrium Thermochim. Acta 1993:221(1):53-62. [Google Scholar] [CrossRef]

[9] Fernandes NS, Carvalho Filho MAS, Melios CB, Ionashiro M. Solid-state Compounds of 4-chlorobenzylidenepyruvate With Lanthanides. Preparation and thermal studies. J. Therm. Anal. Cal. 2000:59(3):663-8. [Google Scholar] [CrossRef]

[10] Marques RN, Melios CB, Ionashiro M. Characterization and thermal behaviour of solid state compounds of 4-methylbenzylidenepyruvate with lighter trivalent lanthanides. J. Alloys Comps 2002:344(1-2):8891. [Google Scholar] [CrossRef]

[11] Marques RN, Melios CB, Ionashiro M. Synthesis, characterization and thermal behaviour of solid state compounds of 4-methylbenzylidenepyruvate with heavier trivalent lanthanides and yttrium(III). Thermochim. Acta 2003:395(1-2):145-50. [Google Scholar] [CrossRef]

[12] Reimer M, Howard M. Addition reactions of unsaturated alpha-ketonic acids II. J. Am. Chem. Soc. 1928:50(9):2506-12. [Google Scholar] [CrossRef]

[13] Ionashiro EY, Fertonani FL, Melios CB, Ionashiro M. Thermal studies of solid 2-methoxybenzylidenepyruvate of lighter trivalent lanthanides. J. Therm. Anal. Cal. 2005:79(2):299-303. [Google Scholar] [CrossRef]

[14] Ionashiro EY, Bannach G, Siqueira AB, Carvalho CT, Rodrigues EC, Ionashiro M. 2-Methoxybenzylidenepyruvatewith heavier trivalent lanthanides and yttrium (III). J. Therm. Anal. Cal. 2008:92(3):953-9. [Google Scholar] [Visualizar Item] [CrossRef]

[15] Nakamoto K. Infrared and Raman Spectra of Inorganic Coordination Compounds. New York: Wiley; 1997. [Google Scholar] 
[16] Deacon GB, Phillips RJ. Relationships between the carbon-oxygen stretching frequencies of carboxylate complexes and the type of carboxylate coordination. Coord. Chem. Rev. 1980:33(3):227-50. [Google Scholar] [Visualizar Item] [CrossRef]

[17] Bannach G, Schnitzler E, Treu Filho O, Utuni VHS, Ionashiro M. Synthesis, characterization and thermal studies on solid compounds of 2-chlorobenzylidenepyruvate of heavier trivalent lanthanides and yttrium(III). J. Therm. Anal. Cal. 2006:83(1):233-240. [Google Scholar] [CrossRef]

[18] Petroni IA, Fertonani FL, Melios CB, Ionashiro M. Synthesis, characterization and thermal behaviour of solid state compounds of 4-methylbenzylidenepyruvate with some bivalent metal ions. Thermochim. Acta 2003:400(1-2):187-98. [Google Scholar] [CrossRef] 